\title{
OESTROUS BEHAVIOUR OF THE EWE AND THE INFLUENCE OF TREATMENT WITH PROGESTAGEN
}

\author{
T. TOMKINS AND M. J. BRYANT \\ Department of Agriculture, University of Reading, \\ Earley Gate, Reading RG6 2AT
}

(Received 25th February 1974)

\begin{abstract}
Summary. Polled Dorset Horn ewes at a progestagen-synchronized oestrus (six ewes) or at a normal oestrus (six ewes) were teased for a 10-min period at 4-hr intervals by a series of different rams. The frequency of nudging, kicking, Flehmen posture, mounting and service by the ram, and of squatting, active soliciting, tail fanning and looking over shoulders by the ewe were recorded.

The mean duration of oestrus \pm S.E. was $48 \cdot 0 \pm 2 \cdot 1 \mathrm{hr}$ for the ewes at a normal oestrus and $51 \cdot 3 \pm 3.5 \mathrm{hr}$ for ewes at a progestagen-synchronized oestrus.

In the 24-hr period before the onset of oestrus, the frequencies of nudging, Flehmen and squatting were greater when the ewes were treated with progestagen.

During oestrus, progestagen treatment produced no major differences in the manifestation of behaviour and some components were of a consistent pattern. At the second of five proportionately equal stages of oestrus, there was a reduction in nudging, Flehmen and squatting which corresponded to an increase in the frequency of tail fanning, looking over shoulders and active soliciting.
\end{abstract}

\section{INTRODUCTION}

The most comprehensive account of oestrous behaviour in the ewe is that by Banks (1964). He describes the major components of sexual behaviour and further describes the behavioural manifestations of oestrus as ranging from a phase of low intensity at the start through a phase of high intensity occurring 8 to $12 \mathrm{hr}$ after commencement, and ending with another phase of low intensity which gradually disappears as the ewe enters the dioestrous stage.

This paper is concerned with a critical description of the behavioural components of the ewe during oestrus in the presence of the ram. An attempt was made to determine the influence of treatment with progestagen on the pattern and occurrence of these components.

It is well established that manifestation of oestrus is under the control of a fine endocrine balance. Ideally, therefore, on cessation of progestagen treatment, the decline of progestagen activity should mimic that following regression of the CL in the normal ewe (Robinson, 1969). 
It has been shown, however, that treatment with progestagen does not result in an identical pattern of production of endogenous oestrogen during and immediately after the terminal stages of treatment. Smith \& Robinson (1970) demonstrated that in ewes treated with progestagen there were two 'surges' of oestradiol production which occurred between $48 \mathrm{hr}$ before oestrus and the onset of oestrus. The latter is earlier than that in the normal ewe. Further evidence of an abnormal endocrine balance at oestrus following progestagen treatment is provided by Cumming, Blockey, Brown, Catt, Goding \& Kaltenbach (1970), who have shown that the LH release in treated ewes occurs 4 to $26 \mathrm{hr}$ before the onset of oestrus, much earlier than in the normal untreated ewe.

Oestrous behaviour has been shown to increase with increasing levels of oestrogen (Fletcher \& Lindsay, 1971). There is a probability, therefore, that the manifestations of behavioural oestrus are altered with progestagen treatment. Fletcher (1971) showed that when oestrus was synchronized in ewes it was significantly shorter. Parsons \& Hunter (1967) and van der Westhuysen, Van Niekerk \& Hunter (1970) also found a similar effect, but the differences were not significant.

The behaviour of the ewe during oestrus cannot be considered in isolation from the behaviour of the ram. The various components of behaviour of the male and female represent links in a chain of events, the reaction of one sex possibly depending upon the action of the other. Components of both ewe and ram behaviour were recorded and are presented in order to provide a comprehensive account of the events during oestrus.

\section{MATERIALS AND METHODS}

The experiment was carried out in the 1 st week of November. Twelve $3 \frac{1}{2}$-yearold Polled Dorset Horn ewes were randomly allocated to two treatments with six ewes per treatment as follows: Treatment $\mathrm{N}=$ normal oestrus; Treatment $\mathrm{T}=$ progestagen-treated or -synchronized oestrus.

Oestrus was synchronized with Veramix vaginal sponges, each containing $60 \mathrm{mg}$ medroxyprogesterone acetate. The sponges were withdrawn on the 13th day after their insertion. For experimental convenience, the ewes allocated to Treatment $\mathrm{N}$ were synchronized one cycle previously and were therefore showing their second oestrus after treatment. Foote \& Waite (1965) consider that the second oestrus after progestagen treatment corresponds to a natural oestrus.

The ewes were individually penned in visual isolation from one another in a brick-built, slatted-floor building. Each pen measured $2 \times 3 \mathrm{~m}$.

Sixteen $1 \frac{1}{2}$-year-old Suffolk rams which were sexually experienced were housed in the same building but in visual isolation from the ewes. The mean liveweight of the rams was $84.5 \mathrm{~kg}$.

The experimental procedure started $12 \mathrm{hr}$ after sponge-removal for the synchronized ewes and $18 \frac{1}{2}$ days ( $444 \mathrm{hr}$ ) after sponge-removal for the normal ewes. At 4-hr intervals, a ram was placed with a ewe for a 10-min 'teasing' period. The sixteen rams were used in strict rotation so that no ram was used more than once in a $4-\mathrm{hr}$ period and no ram met the same ewe more than once 
in $64 \mathrm{hr}$. During each teasing period, the actions of the ram and reactions of the ewe were recorded using an Angus-Esterline multi-pen event recorder and an electric push-button keyboard. Five behavioural characteristics were recorded for the ram and four for the ewe.

It is helpful at this stage to describe briefly the interactions of the ram and ewe during oestrous and non-oestrous conditions before listing the characteristics which were recorded. When the ram approaches a ewe, it generally orientates towards the anogenital region of the ewe and then makes an inspection which is apparently olfactory in nature. A ewe which is not in oestrus responds to this by squatting and urinating and then frequently moves away. The ram makes further olfactory inspections of the urine, generally showing the Flehmen posture. In a field situation, it would seem that the olfactory cues received, together with the withdrawal of the ewe, are usually sufficient to satisfy the ram as to the sexual state of the ewe. The ram will then continue to search for an oestrous ewe. In some cases, the cues are not sufficient and the ram continues the 'approach' behaviour, kicking and nudging the ewe and vocalizing softly. A ewe which is not in oestrus withdraws rapidly when this behaviour commences. The oestrous ewe stands firm and the ram continues to display courtship behaviour before mating with the ewe. The ewe performs several discrete activities during the period of courtship and mating, apparently in response to the activities of the ram.

The characteristics recorded in the present experiment (as frequency of occurrence) were based on our own preliminary observations and those described in detail by Hafez (1952), Banks (1964), and Bermant, Clegg \& Beamer (1969). For the ram, these were:

1. Kicking. The ram orientates behind the ewe and one or other fore-leg is raised and lowered in a stiff-legged striking manner.

2. Nudging with head. Lowering and tilting of the head sideways while the left or right shoulder is brought into contact with or orientated towards the right or left flank of the ewe. At the same time, the ram frequently utters lowpitched vocalizations.

3. Flehmen posture. The male response to the urination of the ewe; the ram sniffs the urine and then extends the neck with the head held high and the top lip upcurled.

4. Mount. The ram straddles the hind quarters of the ewe and commences pelvic thrusting but service is not achieved.

5. Service. The ram accomplishes intromission and ejaculation. The service is characterized by the accompanying deep pelvic thrust, which is used as an indication that service has occurred.

For the ewe, the recorded characteristics were:

6. Squatting. The ewe adopts the typical urination posture and usually does urinate.

7. Active soliciting. The ewe characteristically nudges the genitalia or head regions of the ram.

8. Tail fanning. The repeated movement of the tail in a horizontal plane. During the motion the tail is usually lifted slightly. 
9. Looking over shoulders. A very marked characteristic of the oestrous ewe when present with the ram. It is associated with standing still to allow copulation.

A ewe was recorded as being in oestrus from the time of first standing to be mounted. Recording was discontinued when the ewe failed to stand for a mount during two consecutive teasing periods with two different rams. The onset of oestrus was then considered as having occurred $2 \mathrm{hr}$ before the first teasing period when standing for a mount, and the end of oestrus was considered as having occurred $2 \mathrm{hr}$ after the teasing period with the last recorded stand for a mount.

Recording was done by a team of observers trained by a preliminary series of observations and with the use of ciné film sequences of behaviour. During each teasing period, there were two observers present, one recording ram behaviour and the other recording ewe behaviour.

\section{RESULTS}

No attempt was made to quantify the arrangement of the various ewe and ram components of behaviour into sequences but it was observed that the interactions of the ram and ewe in the experimental situation were similar to those encountered in the field situation. In our experiments, however, non-oestrous ewes were often chased by the ram for much of the teasing period. Possibly the limited space provided in the testing pen allowed only restricted withdrawal by the ewe and thus an inadequate or incomplete signal of sexual state.

All the ewes exhibited oestrus during the observation period. The duration of oestrus of the untreated ewes was $48 \cdot 0 \pm 2 \cdot 1 \mathrm{hr}$ (mean \pm S.E.) which was not significantly different from the mean duration of oestrus of the treated ewes of $51 \cdot 3 \pm 3.5 \mathrm{hr}$. The mean time to onset of oestrus after removal of the sponge from the treated ewes was $27 \cdot 1 \pm 4 \cdot 2 \mathrm{hr}$.

The mean frequencies of the behavioural components for teasing periods during the 24-hr period before oestrus and the teasing periods during oestrus for Treatments $\mathrm{N}$ and $\mathrm{T}$ are shown in Table 1. The differences between the means of the $\mathrm{N}$ and $\mathrm{T}$ ewes and between the period before oestrus and oestrus were compared by Student's $t$ test. The mean frequency of the kicking component was greater during oestrus than during the $24 \mathrm{hr}$ before oestrus for both Treatment $N(P<0.05)$ and Treatment $T$ animals $(P<0.01)$. The mean frequency of nudging and Flehmen posture was lower during oestrus in Treatment T ewes only $(P<0.001)$. By definition, there were no mounts or services before oestrus. The mean frequency per teasing period of the squatting component was lower during oestrus than during the $24 \mathrm{hr}$ before oestrus only in Treatment $\mathrm{T}$ ewes $(P<0.001)$. The mean frequencies of the other three ewe components, tail fanning, looking over shoulders and active soliciting, were all greater during oestrus than in the 24-hr period before oestrus for ewes in both groups $(P<$ $0 \cdot 001)$.

During the 24-hr period before oestrus, the mean frequency per teasing period of nudging and Flehmen was greater for group $T$ ewes $(P<0.001$ and $P<0 \cdot 05$, respectively), and the mean frequency of squatting was also greater 
in Treatment $\mathrm{T}$ ewes $(P<0.001)$. Before oestrus, the mean frequency of active soliciting was greater for Treatment $\mathrm{N}$ ewes $(P<0 \cdot 05)$. During oestrus, the mean frequency per teasing period only differed between Treatments $\mathrm{N}$ and $\mathrm{T}$ for Flehmen which was lower with Treatment $\mathrm{T}$ ewes $(P<0.05)$ and for squatting which was greater in Treatment $\mathrm{T}$ ewes $(P<0.05)$.

Since the duration of oestrus was not the same for each ewe, direct comparisons between the frequency of the behavioural components for Treatments $\mathrm{N}$ and $T$ at each teasing period were not possible as the ewes were at different stages of oestrus. For this reason, the oestrus of each individual ewe was divided into five proportionately equal stages. This enabled the mean frequency \pm S.E. of the behavioural components at each stage of oestrus to be calculated (Table 2). The figures presented are the means of the total frequency per stage of

Table 1. The frequency per teasing period of the behavioural components of rams and ewes during the $24 \mathrm{hr}$ before and during normal and progestagen-synchronized oestrus

\begin{tabular}{|c|c|c|c|c|}
\hline \multirow[t]{2}{*}{ Behavioural components } & \multirow[t]{2}{*}{ Treatment } & \multicolumn{2}{|c|}{$\underset{\text { peariod }}{\text { Mean frequency } \pm S . E . ~ p e r ~ t e a s i n g}$} & \multirow{2}{*}{$\begin{array}{l}\text { Significance } \\
\text { before oestrus } \\
\text { versus oestrus }\end{array}$} \\
\hline & & $24 \mathrm{hr}$ before oestrus & During oestrus & \\
\hline Kicks (ठ̋) & $\begin{array}{l}\text { Normal }(\mathrm{N}) \\
\text { Treated }(\mathrm{T}) \\
\mathrm{N} \text { versus } \mathrm{T}\end{array}$ & $\begin{array}{c}6 \cdot 62 \pm 1 \cdot 87 \\
5 \cdot 71 \pm 1 \cdot 15 \\
\text { N.S. }\end{array}$ & $\begin{array}{c}11 \cdot 5 \pm 1 \cdot 2 \\
9 \cdot 7 \pm 1 \cdot 2 \\
\text { N.S. }\end{array}$ & $*$ \\
\hline Nudges $\left({ }^{*}\right)$ & $\begin{array}{l}\text { Normal } \\
\text { Treated } \\
\mathrm{N} \text { versus } \mathrm{T}\end{array}$ & $\begin{array}{c}4 \cdot 35 \pm 1 \cdot 38 \\
19 \cdot 48 \pm 2 \cdot 6 \\
* * *\end{array}$ & $\begin{array}{c}8 \cdot 2 \pm 1 \cdot 5 \\
8 \cdot 5 \pm 1 \cdot 0 \\
\text { N.S. }\end{array}$ & N.S. \\
\hline Flehmen $(\delta)$ & $\begin{array}{l}\text { Normal } \\
\text { Treated } \\
\mathrm{N} \text { versus } \mathrm{T}\end{array}$ & $\begin{array}{c}3 \cdot 3 \pm 0 \cdot 5 \\
5 \cdot 2 \pm 0 \cdot 5 \\
* *\end{array}$ & $\begin{array}{c}2 \cdot 3 \pm 0 \cdot 3 \\
1 \cdot 1 \pm 0 \cdot 2 \\
*\end{array}$ & N.S. \\
\hline Mounts ( $\left.\tilde{d}^{\pi}\right)$ & $\begin{array}{l}\text { Normal } \\
\text { Treated } \\
\mathrm{N} \text { versus } \mathrm{T}\end{array}$ & $\begin{array}{c}0 \\
0 \\
\text { N.S. }\end{array}$ & $\begin{array}{c}3 \cdot 7 \pm 1 \cdot 4 \\
3 \cdot 9 \pm 0 \cdot 3 \\
\text { N.S. }\end{array}$ & $\begin{array}{l}* * * \\
* * *\end{array}$ \\
\hline Services $\left({ }^{*}\right)$ & $\begin{array}{l}\text { Normal } \\
\text { Treated } \\
\mathrm{N} \text { versus } \mathrm{T}\end{array}$ & $\begin{array}{c}0 \\
0 \\
\text { N.S. }\end{array}$ & $\begin{array}{c}2 \cdot 0 \pm 0 \cdot 14 \\
2 \cdot 3 \pm 0 \cdot 13 \\
\text { N.S. }\end{array}$ & $\begin{array}{l}* * * \\
* * *\end{array}$ \\
\hline Squatting (q) & $\begin{array}{l}\text { Normal } \\
\text { Treated } \\
\mathrm{N} \text { versus } \mathrm{T}\end{array}$ & $\begin{array}{c}2 \cdot 2 \pm 0.4 \\
9 \cdot 1 \pm 1.2 \\
* * *\end{array}$ & $\begin{array}{c}1.4 \pm 0.2 \\
2 \cdot 5 \pm 0.5 \\
*\end{array}$ & N.S. \\
\hline Fanning tail $($ ( $)$ & $\begin{array}{l}\text { Normal } \\
\text { Treated } \\
\text { N versus } \mathbf{T}\end{array}$ & $\begin{array}{c}0.5 \pm 0.2 \\
0.2 \pm 0.2 \\
\text { N.S. }\end{array}$ & $\begin{array}{c}6.9 \pm 1.2 \\
6 \cdot 1 \pm 0.8 \\
\text { N.S. }\end{array}$ & $\begin{array}{l}* * * \\
* * *\end{array}$ \\
\hline Looking over shoulders ( () & $\begin{array}{l}\text { Normal } \\
\text { Treated } \\
\text { N versus } T\end{array}$ & $\begin{array}{c}3 \cdot 1 \pm 1 \cdot 3 \\
0.6 \pm 0.3 \\
\text { N.S. }\end{array}$ & $\begin{array}{c}14 \cdot 0 \pm 1 \cdot 1 \\
13 \cdot 8 \pm 1 \cdot 3 \\
\text { N.S. }\end{array}$ & *** \\
\hline Active soliciting ( $($ ) & $\begin{array}{l}\text { Normal } \\
\text { Treated } \\
\mathrm{N} \text { versus } \mathrm{T}\end{array}$ & 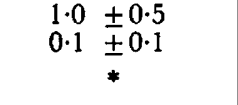 & $\begin{array}{c}7 \cdot 4 \pm 0 \cdot 8 \\
6 \cdot 2 \pm 1 \cdot 2 \\
\text { N.S. }\end{array}$ & $\begin{array}{l}* * * \\
* * *\end{array}$ \\
\hline
\end{tabular}




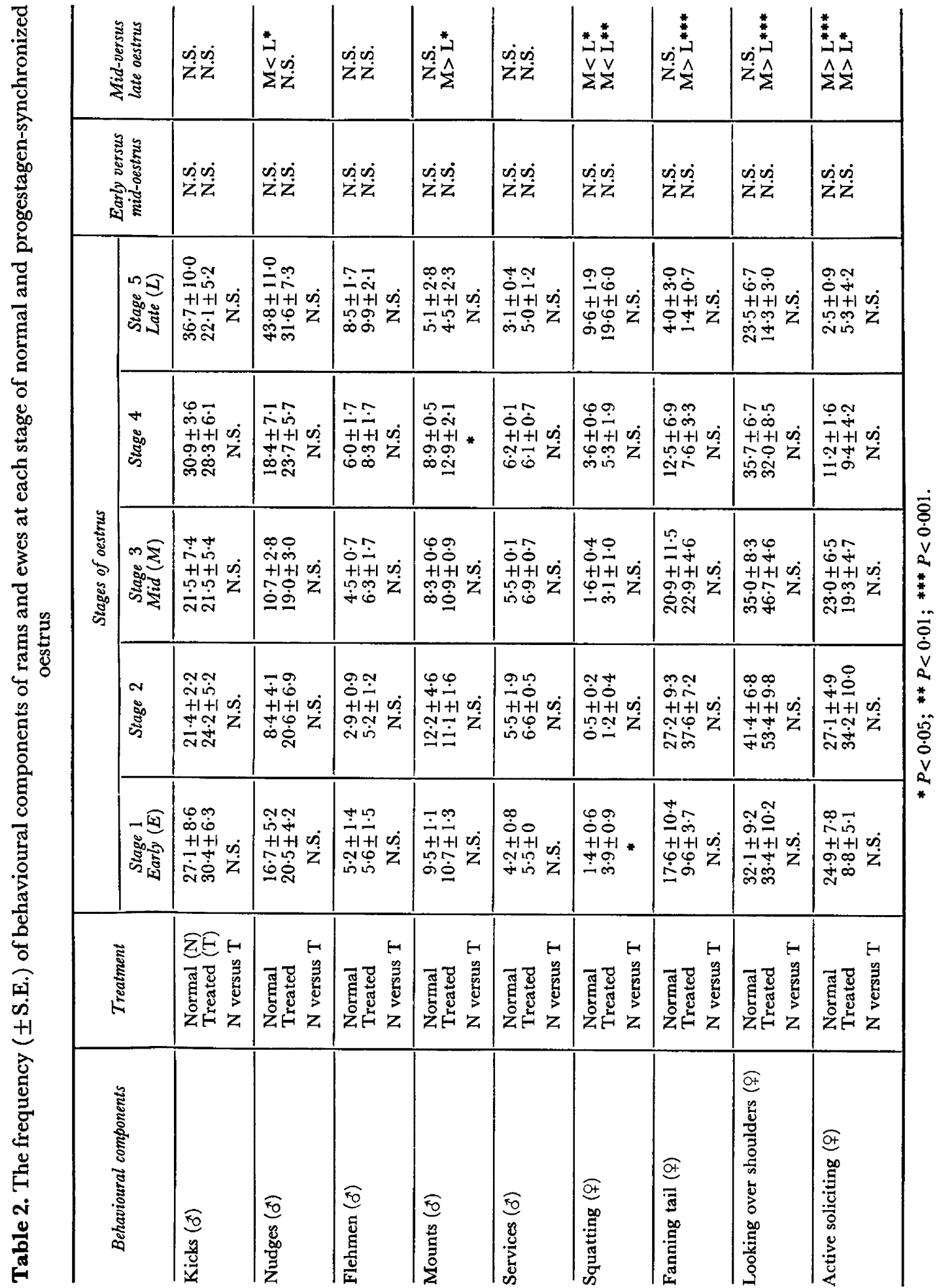


oestrus and not the mean frequency per teasing period per stage of oestrus. It is important, therefore, to distinguish between the figures presented in Table 1 which are 'per teasing period' and those in Table 2 which are 'per stage of oestrus'. For example, if oestrus lasted for ten teasing periods, each 'stage' of oestrus represented two teasing periods and, therefore, the frequency of the behavioural component per stage of oestrus was the addition of the frequencies of two teasing periods.

The arbitrary division of oestrus into five proportionately equal stages enabled comparisons to be made by use of Student's $t$ test between the mean frequency of components for Treatments $\mathrm{N}$ and $\mathrm{T}$ at each stage of oestrus. It also allowed comparisons to be made by a $t$ test between the frequency of the components for early (Stage 1) compared with mid-oestrus (Stage 3),
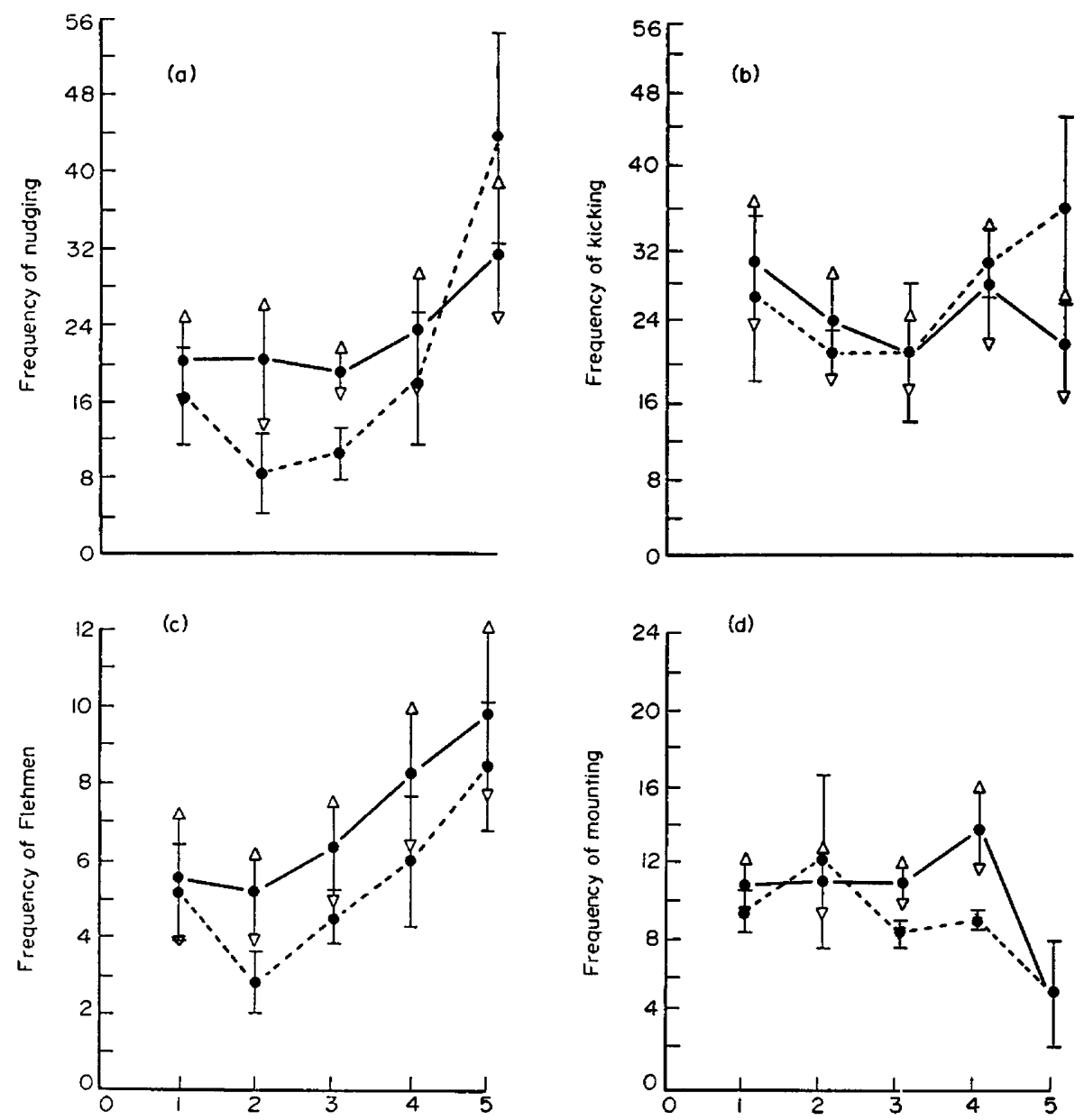

Stage of oestrus

TExT-FIG. 1. The frequency of the ram behavioural components at each of five proportionately equal stages of oestrus: (a) nudging; (b) kicking; (c) Flehmen; (d) number of mounts. - - - - - Normal oestrus;

Vertical bars represent S.E. of means. 
and mid-oestrus (Stage 3) with late oestrus (Stage 5) within treatments. The results of these comparisons are presented in Table 2. The changes in behaviour at each stage of oestrus are represented graphically in Text-fig. 1 for the ram components. The number of services was excluded as there were no significant differences between Treatments $\mathrm{N}$ and $\mathrm{T}$ at any stage of oestrus, or between early and mid-oestrus or mid- and late oestrus within each treatment. The pattern of behaviour of the four ewe components are shown in Text-fig. 2.

There were no significant differences between Treatments $\mathrm{N}$ and $\mathrm{T}$ at any stage of oestrus for any of the components except for the number of mounts which was significantly greater at Stage 4 for Treatment $\mathrm{T}$ ewes $(P<0.05)$. Although there were no significant differences between early and mid- or
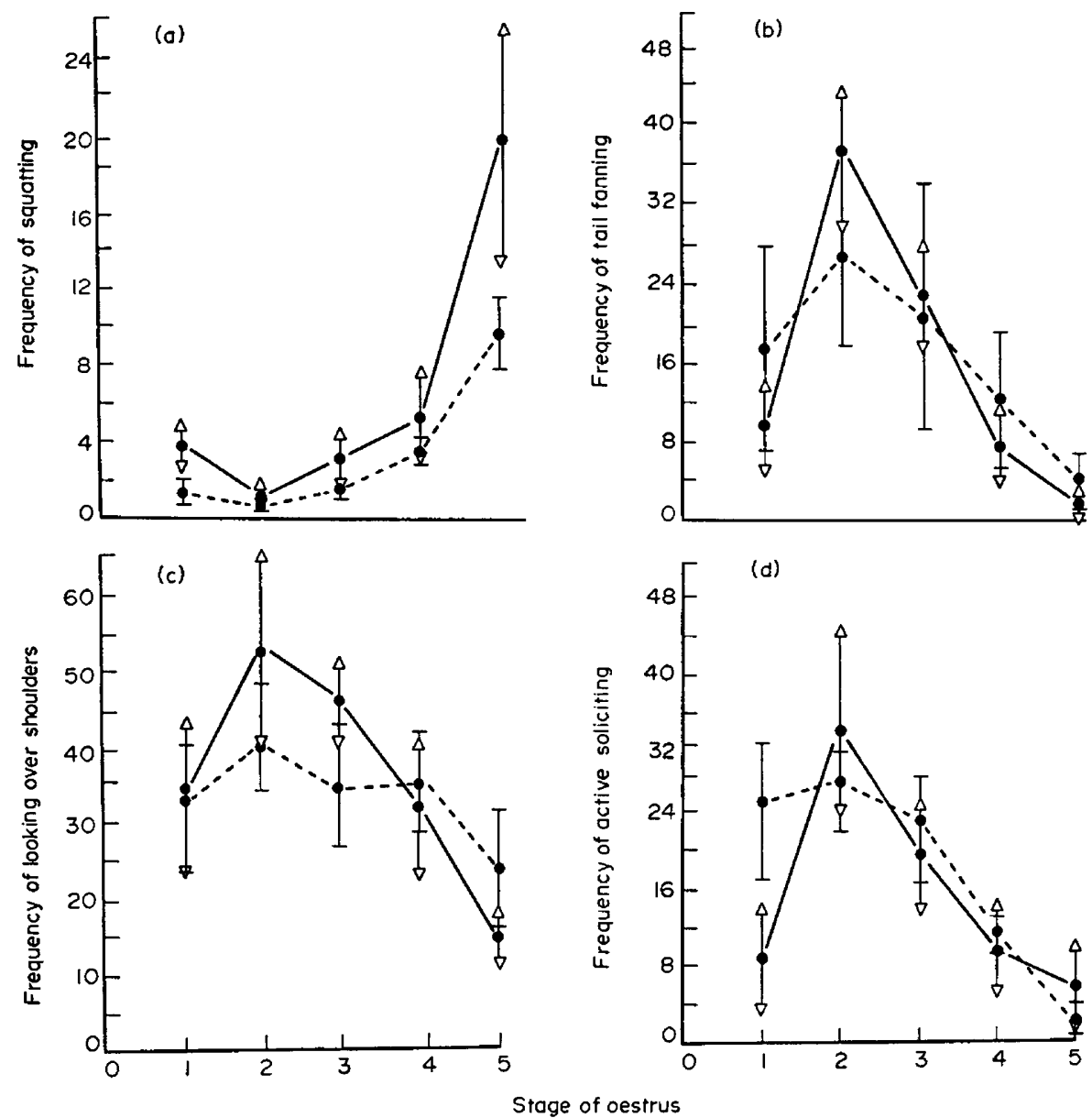

TexT-Fig. 2. The frequency of the ewe behavioural components: (a) squatting; (b) tail fanning; (c) looking over shoulders; (d) active soliciting, at each of five proportionately equal stages of oestrus. - - - - , Normal oestrus;

synchronized oestrus. Vertical bars represent S.E. of means. 


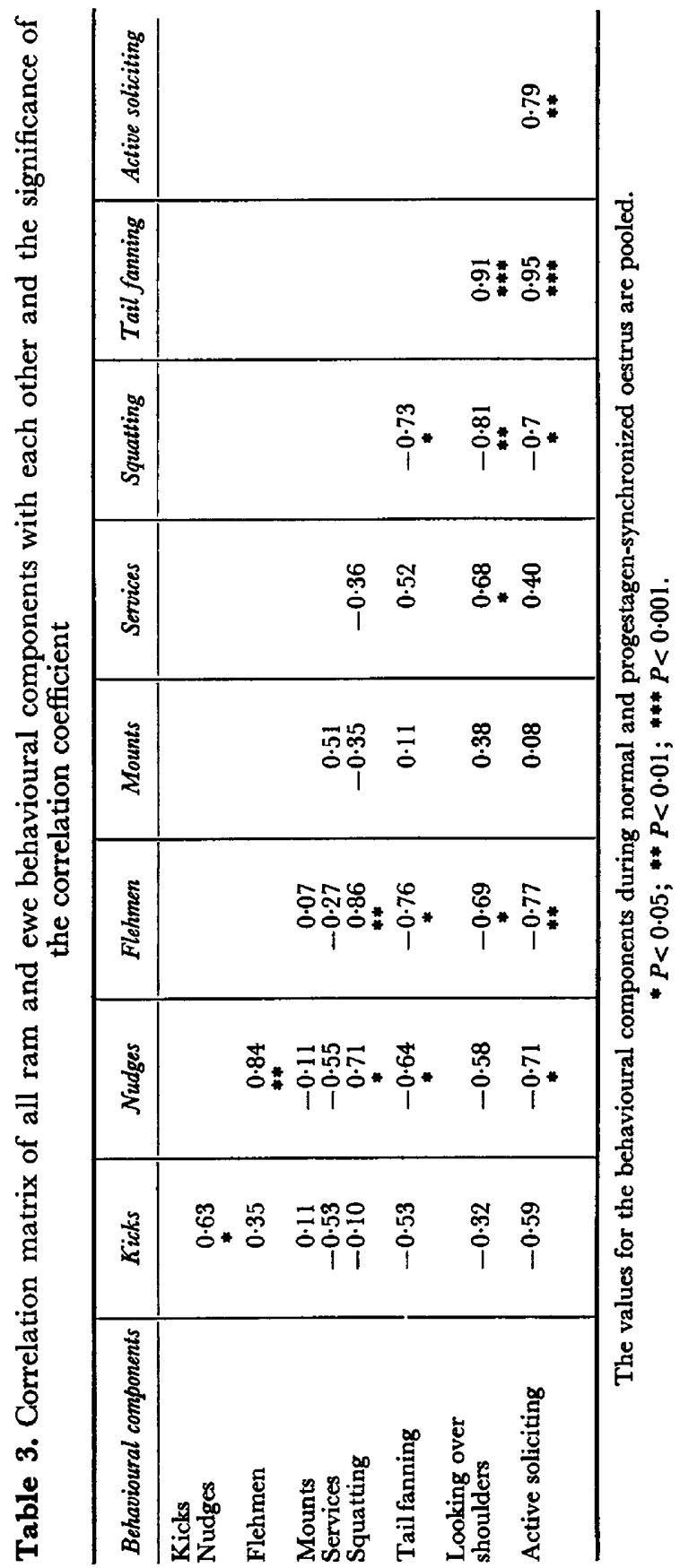


mid- and late oestrus for the frequency of kicking within Treatments $\mathrm{N}$ or $\mathrm{T}$, there appeared to be a trend towards a decline during mid-oestrus (Text-fig. la). The frequency of nudging and Flehmen (Text-figs $1 \mathrm{~b}$ and $1 \mathrm{c}$ ) showed a more marked decrease during mid-oestrus, and the frequency was lower at the start of oestrus than it was at the end for these two components. The number of mounts by the rams was reasonably constant throughout oestrus apart from a decline at late oestrus which was more marked for Treatment $T$ ewes (Textfig. 1d). The frequency of service throughout oestrus was reasonably constant.

The ewe component, squatting, showed a similar trend to the ram components, kicking, nudging and Flehmen. The frequency of squatting was significantly greater in late oestrus for ewes in groups $\mathrm{N}$ and $\mathrm{T}$ (Table 2, Text-fig. 2a). Tail fanning, looking over shoulders and active soliciting appeared to show a very consistent pattern. The frequency increased to a pronounced peak at Stage 2 and then declined progressively at Stages 3, 4 and 5 (Text-figs $2 b, c$ and $d$ ). The frequencies of these three ewe components were lower at late oestrus compared with mid-oestrus for both treatments. The differences were significant in four out of the six comparisons (Table 2). A correlation matrix of all behavioural components is shown in Table 3 . The frequency of kicking was positively correlated with nudging $(P<0.05)$, and the frequency of nudging was correlated with Flehmen $(P<0.05)$ and squatting $(P<0.01)$ but negatively correlated with tail fanning $(P<0.05)$ and active soliciting $(P<0.05)$. The frequency of squatting was negatively correlated with the other three ewe components $(P<0.05)$. The frequency of Flehmen was positively correlated with squatting $(P<0.01)$ and negatively correlated with the other ewe components $(P<0.01)$, which were themselves all positively correlated with each other $(P<0.01)$.

\section{DISCUSSION}

The conditions encountered in the small individual 'test pen' situation of these experiments obviously differ considerably from the 'natural flock' situation and this is one of the disadvantages of the study. It is conceivable that the frequency and timing of some of the behavioural components represent over-estimates of the natural situation.

The method of testing for oestrus is known to influence the over-all duration of behavioural oestrus. Continuous association of the ram and ewe, rather than intermittent teasing by different rams can reduce behavioural oestrus by anything from 6 to at least $24 \mathrm{hr}$ (Parsons \& Hunter, 1967; van der Westhuysen et al., 1970; Fletcher \& Lindsay, 1971). The mean ( \pm S.E.) duration of oestrus of the normal ewes in the present study of $48 \cdot 0 \pm 2 \cdot 1 \mathrm{hr}$ may be compared to $40 \cdot 6 \pm 1 \cdot 2 \mathrm{hr}$ recorded by C. R. C. Hendy (personal communication) for Polled Dorset Horn ewes from the same flock when tested in a similar manner.

Although the duration of oestrus was slightly longer for the ewes treated with progestagen, the effect was apparently not significant. This finding disagrees with the results of Fletcher (1971) who showed that progestagen-treated ewes had a significantly shorter oestrus than normal ewes. Parsons \& Hunter (1967) and van der Westhuysen et al. (1970), however, did not find significant differences between normal and treated ewes. 
From Table 1, it is apparent that the kicking component and the tail fanning, looking over shoulders and active soliciting components are specifically associated with oestrus. Flehmen posture and squatting, however, appear more frequently before than during oestrus. It also appears from Table 1 that ramewe response might be significantly altered by progestagen treatment. The increase in nudging and Flehmen by rams to Treatment $T$ ewes accompanied by the increased squatting response of the ewes might be attributed to the abnormal pattern of production of endogenous oestrogen during and immediately after the terminal stages of progestagen treatment (Smith \& Robinson, 1970). If olfactory cues are involved in sexual behaviour in the ram, as seems likely from the results of Lindsay (1965) and Fletcher \& Lindsay (1968), it is feasible that target tissues involved in pheromone production may be stimulated by such oestrogen release.

During oestrus, the limited differences between treatments suggests that treatment with progestagen has no major influence upon the behavioural manifestations.

It is clear from the results presented in Table 3 and Text-figs 1 and 2 that for some components of behaviour there is a consistent pattern during oestrus. These results confirm the qualitative observations of Banks (1964) that the ewe has a phase of high-intensity behaviour shortly after the beginning of oestrus. The correlation coefficients relating the various behavioural components also confirm Banks' observations; the increase in intensity of ewe behaviour is associated with a significant reduction of courtship activity by the ram.

There is a need to ascertain whether this peak in receptivity in the ewe coincides with any physiological condition that corresponds to an optimum time for insemination for maximum fertility.

Some evidence indicates that this may well be the case. Both Mattner \& Braden (1969) and Killeen \& Moore (1970) have reported that insemination early rather than late in oestrus led to the finding of higher sperm numbers in the cervix, uterus and oviducts as well as a higher fertilization rate.

\section{ACKNOWLEDGMENTS}

We should like to thank Mrs A. Gibbs, Mr J. D. Jenkins and Mr W. Wismans for their valuable assistance during the course of this study. One of us (T.T.) wishes to acknowledge the receipt of a post-graduate scholarship from the Meat and Livestock Commission.

\section{REFERENCES}

BANKs, E. (1964) Some aspects of sexual behaviour in domestic sheep, Ovis aries. Behaviour, 23, 249.

Bermant, G., CleggG, M. T. \& Beamer, W. (1969) Copulatory behaviour of the ram. I. A normative study. Anim. Behav. 17, 700.

Cumming, I. A., Blockey, M. A. de B., Brown, J. M., Catt, K. J., Goding, J. R. \& Kaltenbach, C. C. (1970) The release of luteinizing hormone in ewes following the withdrawal of intravaginal sponges containing progestagen. Proc. Aust. Soc. Anim. Prod. 8, 383.

FLETCHER, I. G. (1971) Effects of oestrogen on the fertility of ewes at a progesterone-synchronised oestrus. Aust. F. agric. Res. 22, 821.

Fletcher, I. G. \& LindSAy, D. R. (1968) Sensory involvement in the mating behaviour of domestic sheep. Anim. Behav. 16, 410. 
Fletcher, I. G. \& Lindsay, D. R. (1971) Effect of rams on the duration of oestrous behaviour in ewes. F. Reprod. Fert. 25, 253.

Foote, W. C. \& WATTE, A. B. (1965) Some effects of progesterone on estrous behavior and fertility in the ewe. F. Anim. Sci. 24, 151.

HAFEZ, E. S. E. (1952) Studies on the breeding season and reproduction in the ewe. V. Mating behaviour and pregnancy diagnosis. F. agric. Sci., Camb. 42, 255.

KilleEN, I. D. \& Moore, N. W. (1970) Transport of spermatozoa and fertilisation in the ewe following cervical and uterine insemination early and late in oestrus. Aust. F. biol. Sci. 23, 1271.

LiNDSAY, D. R. (1965) The importance of olfactory stimuli in the mating behaviour of the ram. Anim. Behav. 13, 75 .

MAtTNER, P. E. \& Braden, A. W. H. (1969) Effect of time of insemination on the distribution of spermatozoa in the genital tract in ewes. Aust. F. biol. Sci. 22, 1238.

Parsons, S. D. \& Hunter, G. L. (1967) Effect of the ram on the duration of oestrus in the ewe. $\mathcal{J}$. Reprod. Fert. 14, 61.

Rosinson, T. J. (1969) The synchronisation of the oestrous cycle and fertility. Proc. 6th Int. Congr. Anim. Reprod. \& A.I., Paris, 2, 1347.

Smith, J. F. \& Robinson, T. J. (1970) The effect of exogenous progestagen on the levels of free oestrogen in the ovarian vein plasma of the ewe. F. Endocr. 48, 485.

van der Westhuysen, J. M., Van Niekerk, G. H. \& Hunter, G. L. (1970) Duration of oestrus and time of ovulation in sheep: effect of synchronisation, season and ram. Agroanimalia, 2, 131. 